UDC 911.3

Liydmila Borisivna Polishchuk,

$\mathrm{PhD}$ (Geography), Associate Professor, Department of Physical Geography and Cartography,

Faculty of Geology, Geography, Recreation and Tourism, V. N. Karazin Kharkiv National University,

4 Svobody Sq., Kharkiv, 61022, Ukraine,

e-mail: 1.polischuk@physgeo.com, https://orcid.org/0000-0001-9887-9524;

Svitlana Ivanivna Reshetchenko,

$\mathrm{PhD}$ (Geography), Associate Professor, Department of Physical Geography and Cartography,

Faculty of Geology, Geography, Recreation and Tourism, V. N. Karazin Kharkiv National University, e-mail: swet_res@meta.ua, https://orcid.org/0000-0003-0744-4272;

Nadyia Ivanivna Cherkashyna,

Senior Lecturer, V. N. Karazin Kharkiv National University, e-mail: n.cherka@gmail.com, https://orcid.org/0000-0002-4066-2530

\title{
IDENTIFICATION OF CLIMATE CHANGES BASED ON ANTROPOGENIC TRANSFORMATION OF LANDSCAPES
}

\section{Л. Б. Поліщук, С. І. Решетченко, Н. І. Черкашина. ІДЕНТИФІКАЦІЯ ЗМІН КЛІМАТУ НА ОСНОВІ ДОСЛІ-} ДЖЕНЬ АНТРОПОГЕННОї ТРАНСФОРМАЦІї ЛАНДШАФТВВ. У статті акиентовано увагу на тому, що розробка стратегї̈ оптимального сочіально-економічного розвитку регіонів потребує ідентифікації специфічних зв'язків природних, соиіально-економічних утворень та масштабного за наслідками порушення функцій екосистеми планетарного рівня - біосфери. Особливо ие стосується найбільш стійкого до негативного впливу людської діяльності компоненту біосфери - атмосфери та ї̈ кліматичної складової. Інформація щуодо зміни їх стану має вирімальне значення, оскільки господарська діяльність впливає на природні ландшафти та визначає матеріально-енергетичні відносини в довкіллі. Це проявляється 6 створенні різноманіття трансформованих ландшафтів, які пов'язані з певним видом господарювання.

Наслідком антропогенних трансформачій є зміна параметрів та характеристик компонентів природного середовища. Основними завданнями дослідження є: спостереження причинно-наслідкових зв'язків між кліматичними змінами, впливом антропогенної діяльності та реакиією на них ландмафтів; отримання показників трансформації повітряних мас в останні десятиліття; визначення причин та ареалів початкового формування та подальшого розвитку змін клімату. Аналіз стану та трансформації ландиафтів, ідентифікація факторів та потенційних антропогенних небезпек дає можливість визначити особливості змін кліматичних умов в межах Харківського регіону. Використання індикаторів спрощує інтерпретачію даних, допомагає виявити нерачіональні підходи у природокористуванні та формуванні природногосподарських систем. Наведені результати вивчення низки параметрів стану кліматичних умов регіону та особливостей антропогенної трансформащії ландшафтів вказують на найбільш вірогідні джерела регіональних змін клімату. Подальша прогностична оцінка циих змін забезпечить вироблення необхідних заходів та умови послідовної їх реалізації в господарській діяльності.

Ключові слова: атмосфера, біорізноманіття, біосфера, гідрометеорологічні прочеси, екосистеми, індикатори змін, клімат, природні ландшафти, трансформачія ландшафтів.

Л. Б. Полищук, С. И. Решетченко, Н. И. Черкашина. ИДЕНТИФИКАЦИЯ ИЗМЕНЕНИЯ КЛИМАТА НА ОСНОВЕ ИССЛЕДОВАНИЯ АНТРОПОГЕННОЙ ТРАНСФОРМАЦИИ ЛАНДШАФТОВ. В статье акцентировано внимание на разработке стратегии оптимального сочиально-экономического развития регионов, которая требует идентификации специфических связей природных, сочиально-экономических образований и масштабного, глубокого за последствиями нарушения функиий экосистемы планетарного уровня - биосферы. Особенно это касается более устойчивого к негативному влиянию человеческой деятельности компонента биосферы - атмосферы и ее климатических составляющих. В соответствии с рациональными условиями использования природных ресурсов информация о изменении их состояния имеет решающее значение в практических исследованиях, поскольку хозяйственная деятельность влияет на природные ландшафты и определяет материально-энергетические отношения в окружающей среде. Это проявляется в создании разнообразных трансформированных ландшафтов, которые связаны с определенным видом хозяйствования.

Антропогенная трансформация ландшафтов приводит к изменениям параметров и характеристик компонентов природной среды. Основныли заданиями исследования являются: установление причинно-следственных связей между климатогенными изменениями, влиянием антропогенной деятельности и реакцией на них ландшафтов; получение показателей трансформации воздушных течений за последние десятилетия; определение причин и ареалов первоначальных формирований, и дальнейтего развития изменений климата. Идентификачия факторов и анализ степени трансформации ландшафтов в пределах Харьковской области дает возможность определить тенденичю изменений климатических условий. Использование индикаторов упрощает интерпретачию данных, помогает при формировании природно-хозяйственных систем. Дальнейшая прогностическая оченка этих изменений обеспечит разработку необходимых мероприятий оптимизации природопользования и последовательной их реализации в хозяйственной деятельности.

Ключевые слова: атмосфера, биоразнообразие, биосфера, гидрометеорологические процессы, экосистемы, индикаторы изменений, климат, природные ландмафты, трансформачия ландшафтов.

Formulation of the problem. In recent decades observation of climatic processes and phenomena has shown changes in the functioning of the system at the biospheric level and its global energy im- balance. Functions of natural geosystems are aimed at preserving organization of its structure but economic activity leads to imbalances, reduction of order, loss of internal organization and inability to 
maintain the required stabilization $[11,16]$. Movements of energy flows in horizontal and vertical directions of the atmosphere cause heavy rainfall, flooding, dry weather, storms, heat waves, changes in rainfall patterns and other extreme atmospheric phenomena. It is extremely important, therefore, to find solution to the problems of preserving the ability of the biosphere to self-regulation, selfrestoration based on optimization of anthropogenic loads on natural systems. Identification of global climate change factors requires in-depth research to find out the most active sources of environmental impact [1-5, 8-9, 14, 21].

Estimates of the effects of the global air temperature growth during 2000-2100 show that frequency of repetition increases, extreme temperature values intensify, global air temperature increases by $2-5^{\circ} \mathrm{C}$, the sea level - by $0.6-1.2 \mathrm{~m}$, affecting the economic development and human life safety [22].

Studies related to climate change are identified as priorities in the Concept for the implementation of the state policy in the field of climate change for the period up to 2030 and the Strategy of Low Carbon Development of Ukraine until 2050 (SNRD) $[15,17]$. They are aimed at studying the impact of these changes on environment to develop a strategy for environmentally sound management of the economy and implementation of this strategy in practice.

Analysis of recent research and publications. According to the concept of natural-adapted resource use, the information on changes in the state and characteristics of natural components is very important. These changes are caused by the activity of various enterprises which are the basis for the creation of the national wealth of Ukraine. [6,10]. Climatic parameters of a separate territory may differ from zonal parameters, and in combination with anthropogenic transformation they can affect general conditions of landscapes, lead to the intensification of unfavorable hydrometeorological and exogenous geodynamic processes and phenomena (erosion, deluvial processes, landslides, suffusion, deflation, flooding). It is possible to separate the component of each of them and determine their indicators due to special monitoring research. Indicators of change are the basis for the formation of information blocks to make decisions on socio-economic development and allow consciously to focus on socio-economic, socio-political and environmental issues for different ranks regions.

Identification of previously unsettled parts of the general problem. Global warming has pronounced regional peculiarities. It is necessary to develop measures on climate change responses at national, sectoral and regional levels, as outlined in the draft Strategy for Sustainable Development of
Ukraine by 2020 [17, 18]. Existence of the world economic growth trajectory conditioned by greenhouse gas emission reductions is highlighted in the Sustainable Development Goal for the period up to 2030 approved at the UN Summit in 2015.

Practical significance of the research is connected with the management forms not exceeding natural possibilities of self-sufficiency of a favorable climate. The forecast of climate change will ensure development of the necessary environmental measures and conditions for their consistent implementation. The study of the conservation issues of natural component in natural and economic systems as well as biodiversity conservation is effective in overcoming the crisis. This often goes beyond the attention of the relevant institutions [11].

Natural landscapes are a sensitive indicator of the environment condition, so the use of data on the landscape components characteristics is necessary to assess the relevant changes. Global warming will lead to degradation of ecosystems as these problems are interrelated. Identification of changes in the state of the environment requires high efficiency of research on the development of natural territorial complexes of different levels, improvement of the control system for anthropogenic influence $[13,16]$. Under the influence of changes in the atmosphericocean-drift (AOS) system, connected with the greenhouse effect increase, depletion of freshwater resources, agro-climatic resources, desertification is highly possible on the studied territory and the country as a whole $[1,4,7]$. This will determine further direction of the socio-economic development of the country.

Formulation of the purpose of the article. The purpose of the study is to determine the causes, areas of initial formation, further development of negative meteorological processes and phenomena on the territory of Kharkiv region during the last decades, as well as to study the parameters and causes of air masses transformation, changes in their properties and resistance to anthropogenic impact.

Methods of research are observations with the help of various devices and technical means, as well as the use of cartographic, statistical materials. For integrated observations comprehensive research was carried out within natural and anthropogenic landscapes to obtain information on the transformation of natural processes and phenomena [12]. An integrated approach, using experimental field-based observations and the technology of climatic series analysis with the help of statistical methods for climate information processing, characterized by high accuracy, allow us to determine their spatialtemporal features and future projections to the natural environment. 
Presentation of the main research material. The main factors of landscapes' transformation on the territory of Kharkiv region are the high level of land, water, mineral and forest resources development, a significant production density, intensive urbanization processes, the structure of the land fund. Most land has agricultural purpose and has been intensively used in the agrarian sector for a long time. $[6,13]$. Acidification of chernozems, pollution due to anthropogenic activity reduces the value of cultivating crops and the quality of soil, which loses its productive functions $[12,16]$.

Circulating atmospheric processes representing a mechanism for the exchange of different temperature characteristics by air masses, play a significant role in the formation of climatic conditions of Kharkiv region. A climatic regime of the territory is formed at the surface of the earth due to the transfer of heat and moisture, where the synoptic processes of the eastern type predominate [9]. Within the limits of this research the parameters of air temperature, monthly rainfall and wind speed were obtained, allowing us to calculate their deviation from the climatic norm and to reveal the tendencies of their further changes. Air transformation continues as a result of interaction with the underlying surface through the processes of heat exchange (accompanied by evaporation and drying of the underlying surface), and as a result of vertical inflow (outflow) of energy through mixing, which leads to the dry air income from the upper levels to the earth's surface.

The climatic ranges of air temperature, rainfall and wind speed are derived from the observation data at ten meteorological stations of the Kharkiv Regional Center for Hydrometeorology of the Ministry for Emergencies of Ukraine during 2001-2016 and belong to various (agro-climatic) zones of Ukraine.

At the surface of the earth, growth of the temperature in the lower atmosphere is caused by the heat transfer between the underlying surface and the adjacent layer of air. In the case of heating, this results in the maximum values of air temperature.

Anthropogenic climate transformations are superimposed on natural characteristics and lead to an increase in average annual air temperatures in the range from 1.1 to $1.4^{\circ} \mathrm{C}$ (Fig. 1).

The greatest warming is observed in winter at stations Velykyi Burluk $\left(1.8^{\circ} \mathrm{C}\right)$, Kolomak $\left(1.7^{\circ} \mathrm{C}\right)$ and Kharkiv $\left(1.4^{\circ} \mathrm{C}\right)$ in accordance with the climate standard (1961-1990). In the spring-summer period, the growth of air temperature was recorded at the stations of Kharkiv $\left(1.2^{\circ} \mathrm{C}\right.$ and $1.7^{\circ} \mathrm{C}$ respectively), Krasnograd $\left(1.1^{\circ} \mathrm{C}\right.$ and $\left.1.5^{\circ} \mathrm{C}\right)$ and Kolomak $\left(1.1^{\circ}\right.$ $\mathrm{C}$ and $\left.1.4^{\circ} \mathrm{C}\right)$. In the autumn there were slight fluctuations in air temperature $\left(1.2^{\circ} \mathrm{C}\right)$.

The analysis of climatic air temperature series for three periods (1891-1935, 1961-1990, 20012016) indicates significant changes in air temperature in the region during 2001-2016, mainly in the winter and summer periods (Figure 2-3).

According to the established criteria the research results show that the temperature of the adjacent atmosphere rises by more than $1.0^{\circ} \mathrm{C}$ in the

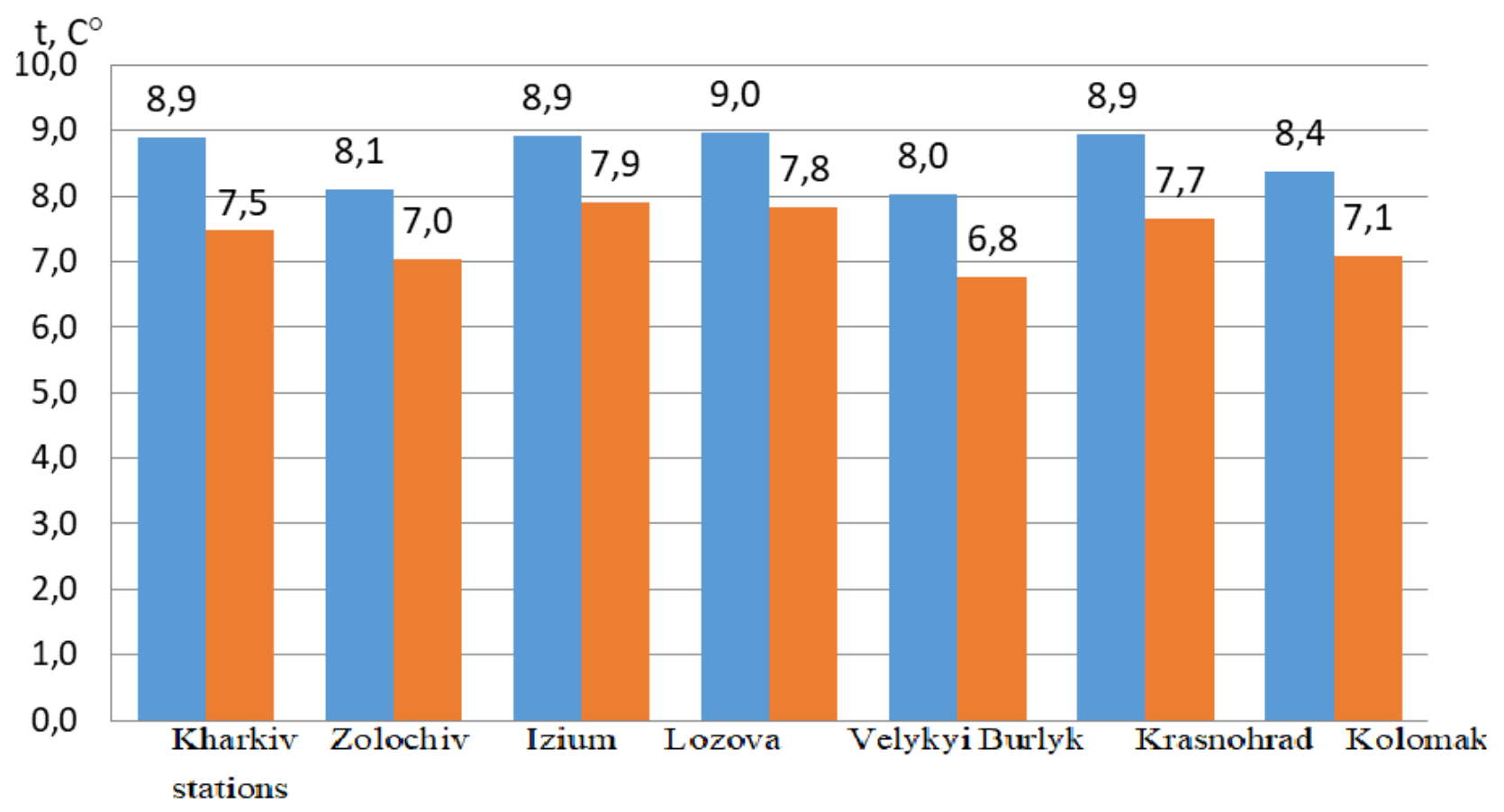

Average air temperature, ${ }^{\circ} \mathrm{C}$

Climatic norm, ${ }^{\circ} \mathrm{C}$

Fig. 1. Dynamics of air temperature on the territory of Kharkiv region 


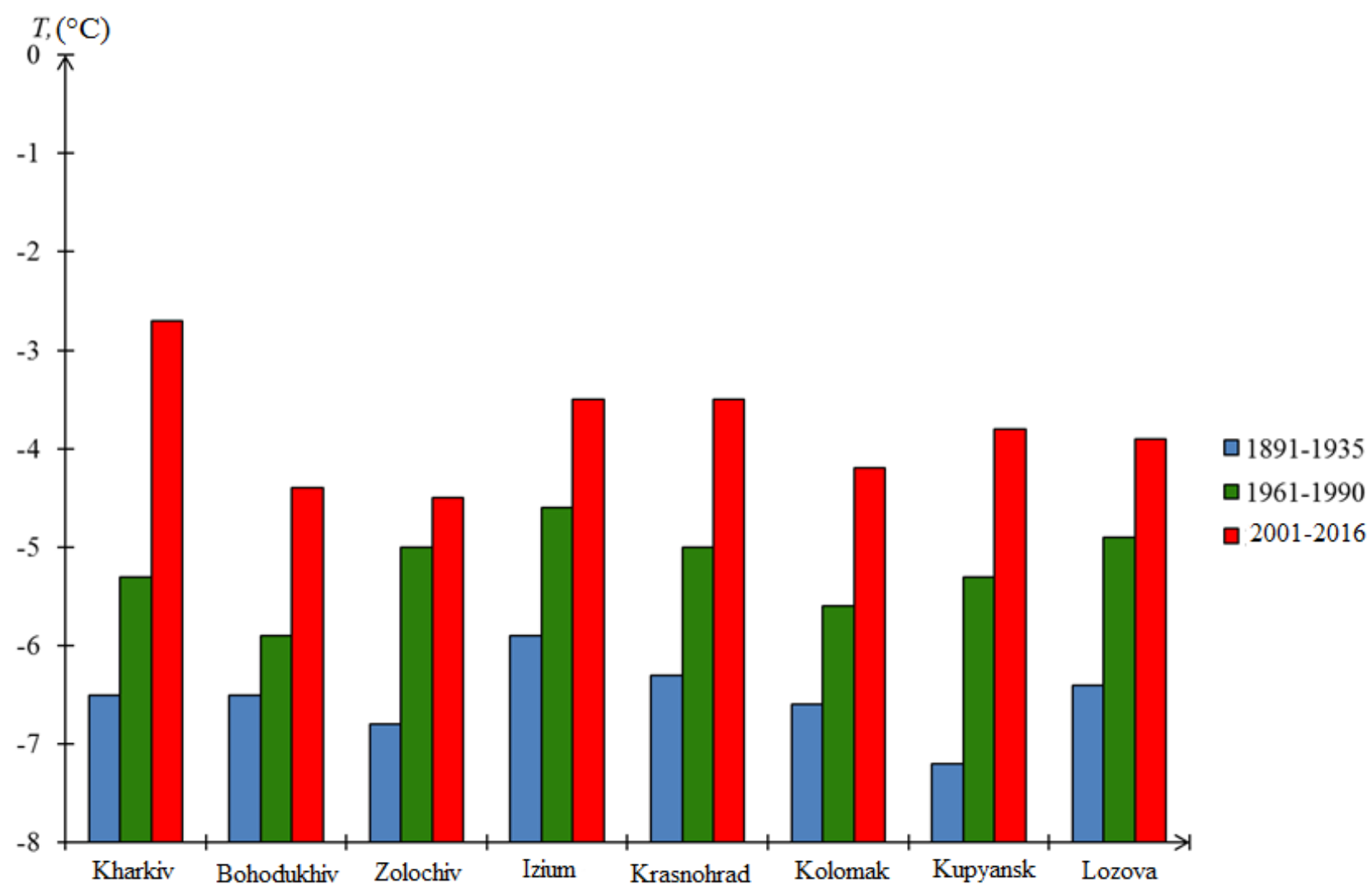

Fig. 2. Dynamics of air temperature on the territory of Kharkiv region (winter)

winter and summer in the territory of Kharkiv region. Significant trends in air temperature are observed in the southwest, south and south-east of the territory within the steppe natural zone. Such conditions are formed when air masses arrive from the southwest and southeast. On the territory of the city of Kharkiv, the air temperature is characterized by maximum deviations from the climatic norm due to the transformation of temperature, precipitation and wind fields.

The peculiarity of the average monthly air temperature dynamics for the period of 2001-2016 at Kharkiv meteorologic station is its growth by $1.6^{\circ} \mathrm{C}$ on average in the winter period (December, January, February), in spring - by $1.0^{\circ} \mathrm{C}$, in summer - by 1,5 ${ }^{\circ} \mathrm{C}$ and in autumn - by $1.2{ }^{\circ} \mathrm{C}$, as compared to the standard climatic norm. In the spring months, the greatest warming occurred in March (by $2.1{ }^{\circ} \mathrm{C}$ ). July (by $2.1^{\circ} \mathrm{C}$ ) and August (by $2.0^{\circ}$ ) were the hottest months compared with the climatic norms. In autumn, the greatest increase in the air temperature was recorded in November (by $1.6^{\circ} \mathrm{C}$ ).

Modern changes in the temperature regime of the investigated area indicate a steady tendency of temperature indices growth throughout the year.

The resulting air temperature trends lead to changes in natural ecosystems, reduced biodiversity, disappearance of natural vegetation and animals. Under the provisions of the CISG (Strategy for Low
Carbon Development by 2050), it is necessary to try to keep the air temperature under the scenario of changing global average temperature below $2^{\circ} \mathrm{C}$ from the preindustrial level.

Results of statistical materials on the direction and wind speed for the period 2001-2016 near the earth's surface at an altitude of $10 \mathrm{~m}$ for the territory of the region is characterized by an increase in the average monthly wind speed in the autumn-winter period (up to $5 \mathrm{~m} / \mathrm{s}$ ). It is established that the prevailing winds are eastern, north-easterly and southern. Fluctuations of the average wind speed for the period under study are characterized by low values $(1 \mathrm{~m} / \mathrm{s})$. It was recorded that the number of strong winds with a speed of more than $10 \mathrm{~m} / \mathrm{s}$ has increased (tabl. 1), causing considerable material damage to the economy: destruction of roofs, blowing crops, destroying trees, wires, structures and causing dangerous waves at large reservoirs [11]. Under such conditions snowstorms forms, damaging the work of transport. Every year up to 15 days during the year with increasing winds are observed.

Within the limits of this research it has been established that the amount of precipitation on the territory is characterized by variability. For the last decades it has undergone significant changes. In the period of 1961-1970, there was an increase in all stations in the region in the winter and decrease in the autumn (Table 2). 


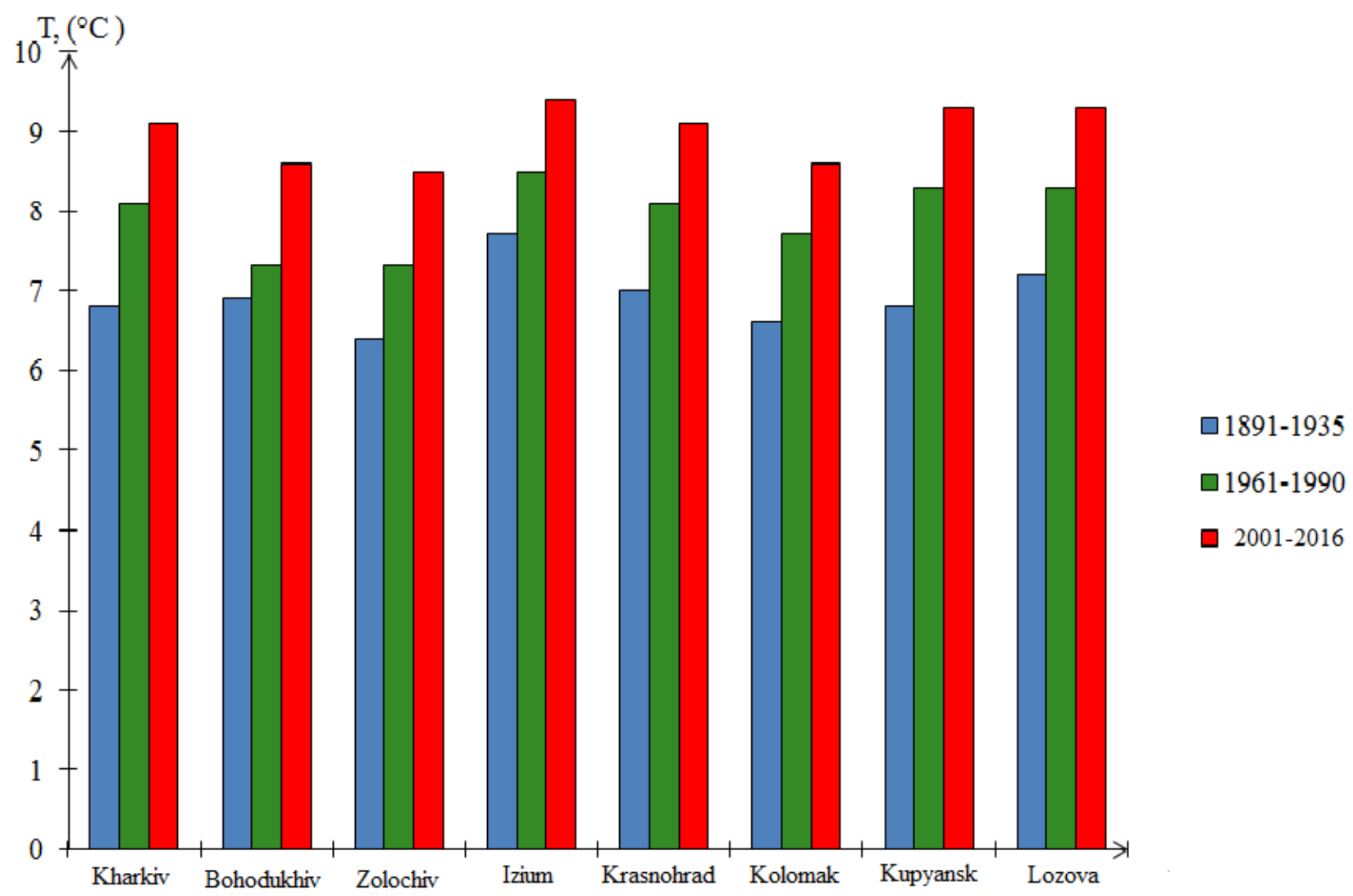

Fig. 3. Dynamics of air temperature on the territory of Kharkiv region (summer)

Table 1

Maximum wind speed at the stations

\begin{tabular}{|c|c|c|c|c|c|c|c|c|c|c|c|c|}
\hline Month & 1 & 2 & 3 & 4 & 5 & 6 & 7 & 8 & 9 & 10 & 11 & 12 \\
\hline Bohodukhiv & 10 & 12 & 15 & 10 & 10 & 13 & 10 & 16 & 11 & 9 & 15 & 12 \\
\hline $\begin{array}{c}\text { Velykyi } \\
\text { Burlyk }\end{array}$ & 11 & 14 & 14 & 12 & 11 & 14 & 12 & 14 & 11 & 12 & 16 & 14 \\
\hline Zolochiv & 8 & 9 & 10 & 10 & 9 & 8 & 8 & 8 & 9 & 7 & 10 & 10 \\
\hline Izium & 9 & 12 & 10 & 10 & 8 & 8 & 10 & 8 & 8 & 10 & 10 & 11 \\
\hline Kolomak & 10 & 12 & 11 & 12 & 11 & 9 & 9 & 10 & 10 & 10 & 12 & 17 \\
\hline Krasnohrad & 8 & 10 & 9 & 8 & 9 & 8 & 6 & 9 & 8 & 7 & 11 & 10 \\
\hline Kupyansk & 9 & 15 & 14 & 10 & 8 & 10 & 10 & 13 & 10 & 10 & 10 & 11 \\
\hline Lozova & 13 & 16 & 15 & 13 & 11 & 10 & 10 & 13 & 10 & 11 & 19 & 16 \\
\hline Kharkiv & 15 & 13 & 13 & 15 & 13 & 13 & 11 & 11 & 11 & 10 & 15 & 12 \\
\hline
\end{tabular}

For the winter period there is a tendency towards decreasing atmospheric precipitation by $1-12$ mm. Only at stations Kupiansk and Slobozhanske in the periods 1981-1990, 2001-2010, the amount of precipitation increased by $1-3 \mathrm{~mm}$ in accordance with the climatic norm (1961-1990). Spring is characterized by an increase in dryness in April and May at the meteorological station of Kharkiv in comparison with the period of 1961-1990. During the summer months (June, July) precipitation was $6 \mathrm{~mm}$ and $1 \mathrm{~mm}$ more than norm, and in August - by contrast (by $7 \mathrm{~mm}$ ). The arid regime was fixed in October. This month, there was $15 \mathrm{~mm}$ less precipitation than the climatic norm. Precipitation exceeded the cli- matic norm in September (by $11 \mathrm{~mm}$ ) and November (by $4 \mathrm{~mm}$ ).

Dry conditions were noticed on the territory of the forest-steppe and the steppes of Kharkiv region mainly in the autumn-winter and summer periods, especially in the south and south-east. In the spring (Table 3) there is a tendency to increased precipitation by $3-15 \mathrm{~mm}$. Since 1991, the amount of precipitation has increased by $2-15 \mathrm{~mm}$ on the territory of the region. According to the results of the average indicators analysis and probability of rainfall, it has been found that their changes in the region are characterized by a large time variability and are of a cyclic nature (after 2-3 years). 
Winter monthly rainfall (1961-2016)

\begin{tabular}{|c|c|c|c|c|c|c|c|c|c|c|c|c|c|c|c|c|c|c|c|c|}
\hline \multirow{2}{*}{ 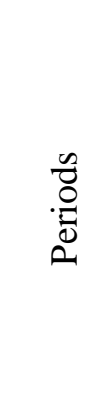 } & \multicolumn{2}{|c|}{$\begin{array}{l}\stackrel{\gtrsim}{\overline{0}} \\
\frac{0}{0} \\
\stackrel{0}{0}\end{array}$} & \multicolumn{2}{|c|}{ 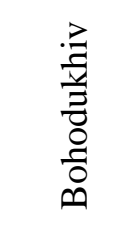 } & \multicolumn{2}{|c|}{ 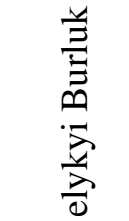 } & \multicolumn{2}{|c|}{ 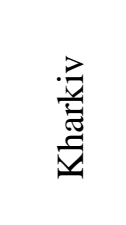 } & \multicolumn{2}{|c|}{ 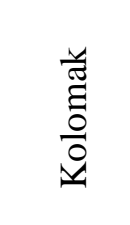 } & \multicolumn{2}{|c|}{ 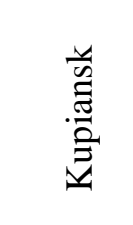 } & \multicolumn{2}{|c|}{ 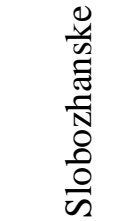 } & \multicolumn{2}{|c|}{ 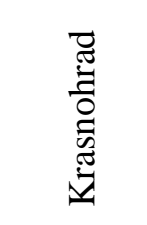 } & \multicolumn{2}{|c|}{ 志 } & \multicolumn{2}{|c|}{ 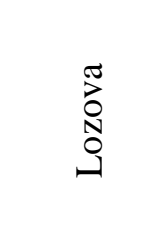 } \\
\hline & $\begin{array}{l}\Sigma \\
\Sigma \\
\Phi\end{array}$ & $\begin{array}{l}\Sigma \\
\Sigma \\
\unlhd \\
\triangleleft\end{array}$ & $\begin{array}{l}\Sigma \\
\Sigma \\
\bar{\Sigma}\end{array}$ & 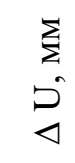 & $\begin{array}{l}\sum_{\Sigma}^{\Sigma} \\
\emptyset \\
\vdots\end{array}$ & $\begin{array}{l}\Sigma \\
\Sigma \\
\unlhd \\
\triangleleft\end{array}$ & $\begin{array}{l}\sum_{\Sigma}^{\Sigma} \\
ص \\
ص\end{array}$ & $\begin{array}{l}\Sigma \\
\Sigma \\
\unlhd \\
\triangleleft\end{array}$ & $\begin{array}{l}\sum_{n} \\
D^{2}\end{array}$ & $\begin{array}{l}\sum_{\Sigma} \\
D^{0} \\
\triangleleft\end{array}$ & $\begin{array}{l}\sum_{\Sigma}^{\Sigma} \\
D^{n}\end{array}$ & $\begin{array}{l}\sum_{\Sigma} \\
\ominus \\
\triangleleft\end{array}$ & $\begin{array}{l}\sum_{\Sigma} \\
\qquad \\
D\end{array}$ & $\begin{array}{l}\sum_{\Sigma} \\
ٍ \\
\downarrow\end{array}$ & $\begin{array}{l}\sum_{\Sigma}^{\Sigma} \\
\triangleright \\
ص\end{array}$ & $\begin{array}{l}\sum_{\Sigma} \\
\qquad \\
\triangleleft\end{array}$ & $\begin{array}{l}\sum_{\Sigma} \\
\supset\end{array}$ & $\begin{array}{l}\sum_{\Sigma} \\
\triangleright\end{array}$ & $\begin{array}{l}\sum_{j} \\
\supset\end{array}$ & $\begin{array}{l}\sum_{\Sigma} \\
\risingdotseq \\
\unlhd\end{array}$ \\
\hline $\begin{array}{l}1961- \\
1970\end{array}$ & 48 & +5 & 53 & +11 & 59 & +9 & 45 & +5 & 59 & +10 & 54 & +7 & 48 & +5 & 60 & +13 & 55 & +7 & 61 & +12 \\
\hline $\begin{array}{l}1971- \\
1980 \\
\end{array}$ & 38 & -5 & 37 & -5 & 45 & -5 & 37 & -3 & 44 & -5 & 42 & -5 & 36 & -7 & 40 & -7 & 44 & -4 & 43 & -6 \\
\hline $\begin{array}{l}1981- \\
1990\end{array}$ & 42 & -1 & 36 & -6 & 47 & -3 & 39 & -1 & 45 & -4 & 44 & +3 & 44 & +1 & 40 & -7 & 46 & -4 & 44 & -5 \\
\hline $\begin{array}{l}1991- \\
2000\end{array}$ & 36 & -7 & 34 & -8 & 37 & -13 & 34 & -6 & 39 & -10 & 39 & -8 & 38 & -5 & 36 & -11 & 44 & -4 & 37 & -12 \\
\hline $\begin{array}{l}2001- \\
2010\end{array}$ & 41 & -2 & 37 & -5 & 42 & -8 & 38 & -2 & 45 & -4 & 48 & +1 & 46 & +3 & 44 & -3 & 48 & $\mathbf{0}$ & 41 & -8 \\
\hline $\begin{array}{l}2011- \\
2016\end{array}$ & 43 & $\mathbf{0}$ & 40 & -2 & 42 & -8 & 39 & -1 & 45 & -4 & 47 & $\mathbf{0}$ & 43 & $\mathbf{0}$ & 44 & -3 & 45 & -3 & 39 & -10 \\
\hline Norm & 4 & & 4 & 2 & 5 & & 4 & & & & 4 & & 4 & & & & 4 & & & 9 \\
\hline
\end{tabular}

It can be noted that rainfall distribution is uneven on the territory by the seasons and in separate months. There are significant fluctuations in precipitation amplitude from year to year, most noticeable in summer and winter. In the course of the month the variability of precipitation remaines significant, confirming the probability of rainfalls.

The tendency of changes to increase the average temperature of air, which affects the state of plants, provokes early flowering and early leaf loss.

Spring monthly rainfall (1961-2016)

\begin{tabular}{|c|c|c|c|c|c|c|c|c|c|c|c|c|c|c|c|c|c|c|c|c|}
\hline \multirow{2}{*}{$\begin{array}{l}\overrightarrow{0} \\
.00 \\
2\end{array}$} & \multicolumn{2}{|c|}{$\begin{array}{l}\stackrel{2}{0} \\
\frac{0}{0} \\
0 \\
0\end{array}$} & \multicolumn{2}{|c|}{ 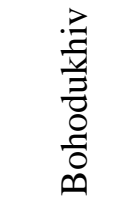 } & \multicolumn{2}{|c|}{ 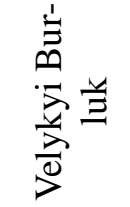 } & \multicolumn{2}{|c|}{ 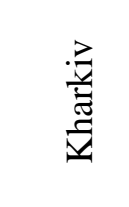 } & \multicolumn{2}{|c|}{$\begin{array}{l}\frac{y}{\pi} \\
\frac{0}{0} \\
\frac{0}{0} \\
\Delta\end{array}$} & \multicolumn{2}{|c|}{ 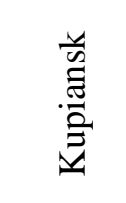 } & \multicolumn{2}{|c|}{ 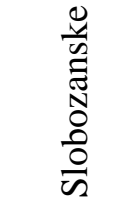 } & \multicolumn{2}{|c|}{ 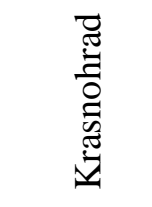 } & \multicolumn{2}{|c|}{ 㲵 } & \multicolumn{2}{|c|}{ 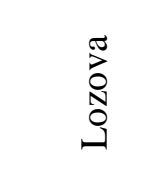 } \\
\hline & $\begin{array}{l}\sum_{\Sigma}^{\Sigma} \\
\underbrace{\prime}\end{array}$ & $\begin{array}{l}\sum_{j} \\
\emptyset \\
\triangleleft\end{array}$ & $\begin{array}{l}\sum_{\Sigma} \\
\vdots \\
\vdots\end{array}$ & $\begin{array}{l}\sum \\
\vdots \\
\searrow\end{array}$ & $\begin{array}{l}\bar{\Sigma} \\
\rho^{\prime}\end{array}$ & $\begin{array}{l}\sum \\
\Sigma \\
\unlhd \\
\unlhd\end{array}$ & $\begin{array}{l}\sum \\
\Sigma \\
D\end{array}$ & $\begin{array}{l}\sum \\
\sum \\
\triangleright \\
\triangleleft\end{array}$ & $\begin{array}{l}\Sigma \\
\Sigma \\
\triangleright\end{array}$ & $\begin{array}{l}\sum_{j} \\
\emptyset \\
\searrow\end{array}$ & $\begin{array}{l}\sum_{\Sigma} \\
ص \\
ص\end{array}$ & $\begin{array}{l}\sum_{\Sigma} \\
\triangleright \\
\triangleleft \\
\triangleleft\end{array}$ & $\begin{array}{l}\sum_{\Sigma} \\
\vdots \\
\vdots\end{array}$ & $\begin{array}{l}\sum \\
\Sigma \\
\triangleright \\
\downarrow\end{array}$ & $\begin{array}{l}\sum_{\Sigma} \\
\emptyset\end{array}$ & $\begin{array}{l}\sum_{\Sigma}^{\Sigma} \\
\vdots \\
\searrow\end{array}$ & $\begin{array}{l}\sum_{\Sigma} \\
\supset\end{array}$ & 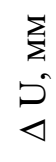 & $\begin{array}{l}\sum_{\Sigma} \\
D^{\prime}\end{array}$ & $\begin{array}{l}\sum \\
\sum^{2} \\
\searrow \\
\triangleleft\end{array}$ \\
\hline $\begin{array}{l}1961- \\
1970\end{array}$ & 39 & +1 & 37 & +1 & 45 & +2 & 37 & +1 & 41 & +1 & 40 & $\mathbf{0}$ & 34 & -3 & 38 & -3 & 43 & +1 & 42 & $\mathbf{0}$ \\
\hline $\begin{array}{l}1971- \\
1980\end{array}$ & 38 & $\mathbf{0}$ & 44 & +6 & 45 & +2 & 41 & +3 & 46 & +4 & 44 & +4 & 38 & +1 & 45 & +4 & 46 & +4 & 49 & +7 \\
\hline $\begin{array}{l}1981- \\
1990\end{array}$ & 38 & $\mathbf{0}$ & 33 & -5 & 39 & -4 & 37 & +1 & 39 & +3 & 35 & -5 & 39 & +2 & 39 & -2 & 36 & -6 & 35 & -7 \\
\hline $\begin{array}{l}1991- \\
2000\end{array}$ & 45 & +7 & 48 & +10 & 45 & +2 & 42 & +4 & 48 & +6 & 48 & +8 & 51 & +14 & 50 & +9 & 51 & +9 & 48 & +6 \\
\hline $\begin{array}{l}2001- \\
2010\end{array}$ & 43 & +5 & 41 & +3 & 37 & -6 & 37 & +1 & 45 & +3 & 39 & -1 & 39 & +2 & 43 & +2 & 43 & +1 & 40 & -2 \\
\hline $\begin{array}{l}2011- \\
2016 \\
\end{array}$ & 43 & +5 & 44 & +6 & 46 & +3 & 43 & +5 & 53 & +11 & 48 & +8 & 45 & +8 & 53 & +12 & 45 & +3 & 57 & +15 \\
\hline Norm & 3 & & & & 4 & & & & & & 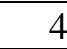 & & - & & & 1 & 42 & & 4 & 2 \\
\hline
\end{tabular}


Due to the spring frosts and absence of pollinating insects, early flowering has a negative effect. There may also be a re-development to which plants are not adapted. The response of plants to climate change is their migration, adaptation and disappearance. Migration changes habitats of plant species, prompting the resettlement of invasive species that displace aboriginal ones. Among them weeds, allergenic plants are especially dangerous. Characteristic are anthropogenic obstacles to migration, especially significant cultivation. Adaptation means gradual adjustment to new environmental conditions. Instead of perennials, annual weeds like plants with a short development cycle, develop [10].

Such changes reduce the energy potential of the biosphere, affect the resources, upsets the supply chains of individual consuments and lead to their extinction. Processes are intensified by the specifics of natural territorial complexes transformation as a result of farming. Disappearance of natural ecosystems is accompanied by death of plant and animal species and biodiversity degradation. Harmful meteorological phenomena have a negative impact on the socio-economic development of the region, reducing crop yields, promoting degradation of soils and depressingly affecting vegetation.

Conclusions. On the basis of the conducted research we have determined the processes influencing climate transformation of Kharkiv region. This makes it possible to construct models for forecasting air temperature and humidity, cloudiness and other meteorological parameters. The air temperature reduces with height, but the reason for its increase can be energy income from external airflows during transformation of air masses. Average air temperature of the surface layer of the atmosphere varies with a speed that goes beyond natural cyclical fluctuations. There is a general tendency towards directed climate change, the so-called "global warming" which threatens natural landscapes, violating and degrading them.

Research on climate change, analysis of the state and transformation of landscapes, identification of factors and potential anthropogenic hazards makes it possible to recognize peculiarities of climatic changes on the territory of Kharkiv region. Optimal management of nature can be successfully implemented in the event of compliance with the levels of the landscape structure: forest-steppe, steppe within Kharkiv region. Study of climate change indicators simplifies data interpretation, helps to identify irrational approaches to environmental management and formation of natural and economic systems. Modern specialization of doing business in the region is not optimal as to the natural conditions, but in many cases is devastating for natural landscapes.

\section{References}

1. Адаменко T.I. Агрокліматичне зонування території України з врахуванням зміни клімату. - Режим доступу: http://www.gwp.org/globalassets/global/gwp-cee_files/idmp-cee/idmpagroclimatic. pdf

2. Вернадский В.И. Биосфера / В.И. Вернадский. - Л.: Географгиз, 1926. - c.139.

3. Гончарова Л.Д. Вплив Північної Атлантики на температуру повітря, опади, атмосферний тиск на лівобережній Украйні / Л.Д. Гончарова, С.І. Решетченко // Український гідрометеорологічний журнал. - № 7. Одеса: TEC, 2010. - C.54-61.

4. Гопченко Е.Д. Оиенка возможных изменений водных ресурсов Украины в условиях глобального потепления / Е.Д. Гопченко, Н.С. Лобода // Гидробиологический журнал. - Киев: Институт гидробиологии НАН Украины. - T. 36. - № 3. $-2000 .-$ C. 67-78.

5. Гребенюк Н.П. Нове про зміни глобального та регіонального клімату в Україні на початку ХХI ст. / Н.П. Гребенюк, Т.В. Корж, О.О. Яценко // Водне господарство України. - 2002. - № 5-6. - С. 34-45.

6. Денисик Г.І. Антропогенні ландшафти Правобережної України: монографія / Г.І. Денисик. - Вінниия: Арбат, 1998. - 292 c.

7. Клімат Украӥни /за ред. В.М.Ліпінського, В.А.Дячука, В.М.Бабіченко. - К.: Вид. Раєвського, 2003. - 343 .

8. Заболоцька Т.М. Небезпечно сильні опади над територією України і можливі причини їх утворення / Т.М. Заболоцька, В.М. Підгурська, Т.М. Шпиталь // Наук. праџі Укр.наук.-дослід.гідрометеорологічного ін.-ту. 2006. - Bun. 255. - C. 21-25.

9. Клімат і загальна цииркуляиія атмосфери: Навчальний посібник / Л.Д. Гончарова, Е.М. Серга, С.П. Школьний. - Київ: КНT, 2005. - 251 c.

10. Лаврик, О.Д. Ідентифікачія стадій розвитку ландшафтно-технічних систем/ О.Д. Лаврик // Вісник Харківського національного університету імені В.Н. Каразіна. Серія:«Геологія. Географія. Екологія». - 2017. Bun.46. - C. 101-105.

11. Поліщук Л.Б. Інтерактивна карта: Охорона природи Харківської області / В.С. Попов, Ю.К. Бурдун, О.О. Карасьов, А.І.Янченко // Проблеми безперервної географічної освіти і картографії: Збірник наукових праць. - Харків : ХНУ імені В.Н. Каразіна, 2015. - Вип. 21. - C.18-21. ScanEx Web GeoMixer: Охорона природи Харківської області [Електронний ресурс]/Режим доступу :http://maps.kosmosnimki.ru/api/index.html? 33655009DAAD43C18AFD0ED7B2898D4 http://goik.univer.kharkov.ua/archive/ вільний. 
12. Поліщук Л.Б. Природні та антропогенні ландшафти як складова знань про довкілля / А.А. Мороз, Р.В. Кравченко // Проблеми безперервної географічної освіти і картографії: Збірник наукових праць. - Вип. 28. - Х.: ХНУ імені В.Н. Каразіна, 2018. - C. 61-67. [Електронний ресурс]. - Режим доступу http://goik.univer.kharkov.ua/archive/issue-28/

13. Ретеюм А.Ю. Взаимодействие техники с природой и геотехнические системы / А.Ю. Ретеюм, К.Н. Дьяконов, Л.Ф. Куницын// Известия АН СССР. Серия географическая. - 1972. - № 4. - C. 46-55.

14. Решетченко C.I. Зміна температурного режиму на території Харківської області / C.I. Решетченко, Т.Г. Ткаченко, О.Г. Лисенко // Вісник Харківського начіонального університету ім. В.Н. Каразіна. Серія: геологія, географія, екологія. - 2015. - Вип. 43. - С. 153-158.

15. Розпорядження Кабінету Міністрів України «Про схвалення Концепиії реалізації державної політики у сфері зміни клімату на період до 2030 року» від 7 грудня 2016 р. - № 932. - Режим доступу: http://www.kmu.gov.ua/control/uk/cardnpd?docid=249573705

16. Руденко В.П. Критичний екологічний стан компонентів природи в регіонах Украӥни // Український географічний журнал. - 2010. - № 2. - С. 60-68.

17. Стратегія низьковуглецевого розвитку України до 2050 р. - Київ, 2017. - 53c.

18. Стратегія розвитку Харківської області на період до 2020 року [Текст] // Харківська обласна державна адміністраиія [Електронний ресурс].- Режим доступу: http://old.kharkivoda.gov.ua/documents/16203/1088.pdf

19. Суздалева А.Л. Управляемые природно-технические системы энергетических и иных объектов как основа обеспечения техногенной безопасности и охраны окружающей среды (темы магистерских диссертаций): учеб. пособ. / А.Л. Суздалева-М.: ИД ЭНЕРГИЯ, 2015. -160 с.

20. Швиденко А.З. Вуглець, клімат та землеуправління в Украӥні: лісовий сектор: монографія / А. Швиденко, П. Лакида, Д. Щепашенко, Р. Василишин, Ю.Марчук. - Корсунь-Шевченківський: ФОП Гавришенко В.М., 2014. $-283 c$.

21. Шосте національне повідомлення Украӥни $з$ питань зміни клімату. - Режим доступу: http://unfccc.int/national_reports/national_communications_and_biennial_reports/submissions/items/7742.php

22. IPCC, 2014: Climate Change 2014: Synthesis Report. Contribution of Working Groups I, II and III to the Fifth Assessment Report of the Intergovernmental Panel on Climate Change [Core Writing Team, R.K. Pachauri and L.A. Meyer (eds.)]. IPCC, Geneva, Switzerland, $151 \mathrm{pp}$.

23. NOAA's HYSPLIT atmospheric transport and dispersion modeling system /A.F. Stein, R.R. Draxler, G.D. Rolph etc/l Bull. Amer. Meteor. Soc. -2015. - № 96. -pp. 2059-2077.

Authors Contribution: All authors have contributed equally to this work.

UDC 911.3

\section{Liydmila Polishchuk,}

$\mathrm{PhD}$ (Geography), Associate Professor, Department of Physical Geography and Cartography, Faculty of Geology, Geography, Recreation and Tourism, V. N. Karazin Kharkiv National University, 4 Svobody Sq., Kharkiv, 61022, Ukraine, e-mail: 1.polischuk@ physgeo.com, https://orcid.org/0000-0001-9887-9524;

\section{Svitlana Reshetchenko,}

$\mathrm{PhD}$ (Geography), Associate Professor, Department of Physical Geography and Cartography, Faculty of Geology, Geography, Recreation and Tourism, V. N. Karazin Kharkiv National University, e-mail: swet_res@meta.ua, https://orcid.org/0000-0003-0744-4272;

Nadyia Cherkashyna,

Senior Lecturer, V. N. Karazin Kharkiv National University, e-mail: n.cherka@gmail.com, https://orcid.org/0000-0002-4066-2530

\section{IDENTIFICATION OF CLIMATE CHANGES BASED ON ANTROPOGENIC TRANSFOR- MATION OF LANDSCAPES}

Formulation of the problem. Functioning of natural geosystems is aimed at preserving their structure, but economic activity leads to imbalances, decreases in order, loss of internal organization and the inability to maintain the necessary stabilization.

Analysis of previous research. Studies of the last decades have shown that the climatic conditions of Ukraine can be unfavorable for the life and economic activity of the society.

Problems of further research. To find the solution to the problem of preserving the ability of the biosphere to self-regulation, self-restoration by optimizing anthropogenic load on natural systems is very important. Identification of climate change factors is aimed at finding the most active sources of environmental impact in order to determine the real threat of global climate change. 
The purpose of the research is to determine the causes, areas of initial formation, further development of negative meteorological processes and phenomena on the territory of Kharkiv region during the last decades and to study parameters and causes of air masses transformation, changes in their properties and various resistance to anthropogenic impact.

Research methods are observation with the help of various devices and technical means. An integrated approach using field-based observations and technology of climatic series analysis with the help of statistical methods for climate information processing, characterized by high accuracy, allow us to determine their spatial-temporal features and future projections to the natural environment.

Presentation of the main research material. Optimal strategic socio-economic development of the regions requires identification of specific links between natural and socio-economic entities, as well as studying large-scale and profound by the consequences violations of the ecosystem at the planetary level - the biosphere and its components. There is a general tendency towards directed climate change, the so-called "global warming", which threatens natural landscapes, upsetting and destroying them.

Practical value. There are causal relationships between climatogenic changes, influence of human activity and the reaction of landscapes to them. This is manifested in creation of a variety of transformed landscapes (agrarian, residential, industrial). The consequence of anthropogenic transformations is the change in the parameters and characteristics of the components of nature.

Research results. Indicators are the basis for information blocks concerning decision-making in the areas of socio-economic development. Climate parameters of a certain territory may differ from zonal ones and in combination with anthropogenic transformation affect the general condition of the landscapes, lead to the intensification of adverse hydrometeorological and exogenous geodynamic processes and phenomena (erosion, deluvial processes, landslides, suffusion, deflation, flooding.

Keywords: atmosphere, biodiversity, biosphere, hydrometeorological processes, indicators of change, climate, natural landscapes, landscape transformation, ecosystems.

\section{References}

1. Adamenko, T.I. Agro-climatic zone zoning of Ukraine taking into account climate change. Available at: http://www.gwp.org/globalassets/global/gwp-cee_files/idmp-cee/idmpagroclimatic. Pdf. [in Ukrainian]

2. Vernadskij, V.I. (1926). Biosphere. L.: Geografgiz, 139. [in Russian]

3. Goncharova, L.D., Reshetchenko, S.I. (2010). Impact of the North Atlantic on air temperature, precipitation, atmospheric pressure on the left-bank Ukraine. Ukrayins `ky`j gidrometeorologichny`j zhurnal, 7, 54-61. [in Ukrainian]

4. Gopchenko, E.D. Loboda, N.S. (2000). Assessment of possible changes in water resources of Ukraine in the context of global warming. Kiev: Institut gidrobiologii NAN Ukrainy, 36 (3), 67-78. [ in Russian]

5. Grebenyuk, N.P., Korzh, T.V., Yacenko, O.O. (2002). New on the changes in the global and regional climate in Ukraine at the beginning of the XXI century. Vodne gospodarstvo Ukrayiny, 5-6, 34-45. [in Ukrainian]

6. Deny`sy`k, G.I. (1989). Anthropogenic landscapes of the Right-Bank Ukraine. Vinny 'cya: Ar-bat, 292. [ in Russian]

7. Lipins`kogo, V.M., et. al. (2003). The climate of Ukraine. K.: Vy`d. Rayevs`kogo, 343. [in Ukrainian]

8. Zabolocz'ka, T.M., Pidgurs'ka, V.M., Shpy'tal, T.M. (2006). Hazardous heavy precipitation over the territory of Ukraine and possible causes of their formation. Nauk. praci Ukr.nauk.-doslid.gidrometeorologichnogo in.-tu, 255, 21-25. [in Ukrainian]

9. Goncharova, L.D., et. al. (2005). The climate and the general circulation of the atmosphere. Ky'yiv: KNT, 251. [in Ukrainian]

10. Lavry`k, O.D. (2017). Identification of stages of development of landscape-technical systems. Visny`k Xar-kivs`kogo nacional'nogo universy'tetu imeni V.N. Karazina. Seriya: Geologiya. Geografiya. Ekologiya, 46, 101-105. [in Ukrainian]

11. Polishhuk, L.B., Popov, V.S., Burdun, Yu.K., Karas'ov, O.O. (2015). Interactive map: Nature conservation in the Kharkiv region. Problemy` bezperervnoyi geografichnoyi osvity` $i$ kartografiyi: Zbirny`k naukovy`x pracz`, Xarkiv, 21, 18-21. Available at: http://maps.kosmosnimki.ru/api/index.html?33655009DAAD43C18AFD0ED7B2898D4 http://goik.univer.kharkov.ua/archive/ vil'ny’j. [in Ukrainian]

12. Polishhuk, L.B., Moroz, A. A., Kravchenko, R.V. (2018). Natural and anthropogenic landscapes as a component of environmental knowledge. Problemy` bezperervnoyi geografichnoyi osvity $i$ kartografiyi, Zbirny`k naukovy`x pracz, 28, 61-67. Avaabe at: http://goik.univer.kharkov.ua/archive/issue-28. [in Ukrainian]

13. Reteyum, A.YU., D'yakonov, K.N., Kunicyn, L.F. (1972). Interaction technology with nature and geotechnical systems. Izvestiya AN SSSR. Seriya geograficheskaya, 4, 46-55. [in Russian]

14. Reshetchenko, S.I., Tkachenko, T.G., Ly'senko, O.G. (2015). Changing the temperature regime in the Kharkiv region]. Visny`k Xarkivs`kogo nacional’nogo universy`tetu im. V.N. Karazina. Seriya: geologiya, geografiya, ekologiya, 43, 153-158. [in Ukrainian]

15. Rozporyadzhennya Kabinetu Ministriv Ukrayiny` «Pro sxvalennya Koncepciyi realizaciyi derzhavnoyi polity`ky` $u$ sferi zminy` klimatu na period do 2030 roku» vid 7 grudnya 2016 r. № 932. [Order of the Cabinet of Ministers of 
Ukraine «On Approval of the Concept of Implementation of the State Policy in the Field of Climate Change for the Period until 2030»]. Available at: http://www.kmu.gov.ua/control/uk/cardnpd?docid=249573705. [in Ukrainian]

16. Rudenko, V.P. (2010). The critical ecological state of the components of nature in the regions of Ukraine. Ukrayins `ky j geografichny j zhurnal, 2, 60-68. [in Ukrainian]

17. Strategy of low carbon development of Ukraine up to 2050. (2017).. Ky yiv, 53. [in Ukrainian]

18. Strategy for the development of the Kharkiv region up to 2020. Xarkivs ka oblasna derzhavna administraciya. Available at: http://old.kharkivoda.gov.ua/documents/16203/1088.pdf. [in Ukrainian]

19. Suzdaleva, A.L. (2015). Managed natural-technical systems of energy and other objects as a basis for ensuring technological safety and environmental protection. M.: ID EHNERGIYA, 160. [ in Russian]

20. Shvy`denko, A.Z., Laky`da, P., Shhepashhenko, D. (2014). Carbon, Climate and Land Management in Ukraine: Forest Sector: Monograph. Korsun'-Shevchenkivs `ky j: FOP Gavry`shenko V.M., 283. [in Ukrainian]

21. The sixth national report of Ukraine on climate change]. Available at: http://unfccc.int/national_reports/national_communications_and_biennial_reports/submissions/items/7742.php. [in Ukrainian]

22. IPCC, 2014: Climate Change 2014: Synthesis Report. Contribution of Working Groups I, II and III to the Fifth Assessment Report of the Intergovernmental Panel on Climate Change [Core Writing Team, R.K. Pachauri and L.A. Meyer (eds.)]. IPCC, Geneva, Switzerland, 151.

23. Stein, A.F., Draxler, R.R., Rolph, G.D. (2015). NOAA's HYSPLIT atmospheric transport and dispersion modeling system, Bull. Amer. Meteor. Soc., 96, 2059-2077. 